\title{
Analysis of Requirements for Entrepreneurship-Based Biotechnology Textbooks at Universitas Negeri Padang
}

\author{
M Yusuf ${ }^{*}$, Yuni Ahda ${ }^{1}$
}

\author{
${ }^{1}$ Biology Department, Math and Natural Science Faculty, Universitas Negeri Padang, Padang, Indonesia \\ *Corresponding author. Email: ymenhil@gmail.com
}

\begin{abstract}
The university has an important role in preparing the nation's generation to take Indonesia's demographic bonus in 2020-2035 in the industrial revolution 4.0. The effort needed to take the demographic bonus is to apply biotechnology lectures that are integrated with entrepreneurship education. The lecture can be held using entrepreneurship-based biotechnology textbooks. Therefore, this research aims to determine the needs of entrepreneurship-based biotechnology textbooks, student experience in entrepreneurial activities and student interest in developing biotechnology knowledge into the field of entrepreneurship. This study uses interviews with biotechnology lecturers and questionnaires for biotechnology students at Universitas Negeri Padang. The result was $96,7 \%$ of students expressed interest in entrepreneurship-based biotechnology teaching materials, $68,5 \%$ had experience in entrepreneurial activities and 89,26\% were interested in developing biotechnology into the entrepreneurship field. But, entrepreneurship-based biotechnology textbooks are not yet available at UNP. Even though entrepreneurship-based biotechnology textbooks are really needed in lectures. Because the textbook can be a reference for Lecturers and Students to develop the idea of applying biotechnology to the realm of entrepreneurship. In the end, through the use of this textbook, graduates of higher education (especially graduates of biology study programs) are expected to have additional provisions in developing their careers in the future.
\end{abstract} Keywords: Textbooks, Biotechnology, and Entrepreneurship.

\section{INTRODUCTION}

The implementation of education in Indonesia is an implementation of the National Education System Law number 20 of 2003. Education is implemented in stages, including the University level. Today, universities have an important role in preparing the nation's generation for competition in the industrial revolution 4.0 era.

The era of the industrial revolution 4.0 is a global transformation in each country and optimizes the use of digital technology in various fields [1]. This era is also believed to provide opportunities for every individual to improve their quality to compete globally. Based on that there is the role of universities to organize education that aims to prepare generations in the industrial 4.0 era.

Literally, universities are expected to be able to make students as religious, healthy, knowledgeable, capable, creative, independent, skilled, competent, and cultured people for the benefit of the nation [2]. In the process of education, every individual who is at the university level will receive a variety of knowledge in accordance with the study program they have. Among the knowledge to be received is Biotechnology in the Biology study program.
Biotechnology is the science of utilizing organisms to support human welfare. Biotechnology has the potential to be applied to the field of entrepreneurship. This is also in accordance with the times that are leading to industry 4.0 and Indonesia will be prepared to take demographic bonuses in 2030-2035.

In an effort to pick up the demographic bonus, biotechnology lectures should be integrated with entrepreneurship material. One way to do the integration is to use entrepreneur-based biotechnology teaching materials during lectures. Therefore, on this occasion researchers will try to explore the needs of entrepreneurship-based biotechnology teaching materials, experience in entrepreneurial activities and student interest in developing biotechnology knowledge in the field of entrepreneurship at Padang State University.

In an effort to take the demographic bonus, biotechnology lectures should be integrated with entrepreneurship material. Lectures can be done using entrepreneur-based biotechnology teaching materials during lectures. Therefore, this study will try to exploit the need for entrepreneurship-based biotechnology textbooks, experience in entrepreneurial activities and student interest 
in developing biotechnology knowledge in the field of entrepreneurship at Universitas Negeri Padang.

\section{METHODS}

This research uses descriptive research method. Data collection uses interviews and questionnaires. Interviews were conducted with biotechnology lecturers at Universitas Negeri Padang and questionnaires were given to biotechnology students.

\section{RESULT AND DISCUSSION}

\subsection{Result}

Based on interviews with biotechnology lecturers, the results show that entrepreneurship-based biotechnology textbooks are not yet available. While the results of the student questionnaire obtained results:

\subsubsection{Student Interest in Textbooks}

Student interest in textbooks in biotechnology lectures was 96.7\% (table 1).

Table 1. Student Interest in Textbooks

\begin{tabular}{|l|l|l|}
\hline No. & Indicator a a & $\%$ \\
\hline 1 & $\begin{array}{l}\text { Requires textbooks as afence for lectures } \\
\text { reference }\end{array}$ & $\begin{array}{l}\text { Agree on the development of } \\
\text { entrepreneurship-based } \\
\text { biotechnology textbooks }\end{array}$ \\
\hline 3 & $\begin{array}{l}\text { Agree if entrepreneurship- } \\
\text { based biotechnology textbooks } \\
\text { provide motivation for } \\
\text { students to open jobs }\end{array}$ & 94,2 \\
\hline Average & 96,7 \\
\hline
\end{tabular}

\subsubsection{Student Experience on Entrepreneur} Activities

Measurement of student experience in entrepreneurial activities is carried out with 3 indicators. The result is $68.5 \%$ of students have experience in entrepreneurial activities (table 2).

Table 2. Student Experience on Entrepreneur Activities

\begin{tabular}{|l|l|c|}
\hline No. & Indicator & $\%$ \\
\hline 1 & $\begin{array}{l}\text { Have experience in making } \\
\text { product development plans to } \\
\text { entrepreneurship? }\end{array}$ & 59,6 \\
\hline 2 & $\begin{array}{l}\text { Have experience in promotional } \\
\text { activities? }\end{array}$ & 63,4 \\
\hline 3 & Have experience in product sales & 82,6 \\
\hline
\end{tabular}

\begin{tabular}{|l|l|}
\hline activities? & \\
\hline Average & 68,5 \\
\hline
\end{tabular}

\subsubsection{Interest in Developing Biotechnology to Entrepreneurship}

Student interest in developing biotechnology to entrepreneurship was $89.26 \%$ (table 3).

Table 3. Interest in Developing Biotechnology to Entrepreneurship

\begin{tabular}{|l|l|l|}
\hline No. & Indicator & $(\%)$ \\
\hline 1 & $\begin{array}{l}\text { Interested in entrepreneurial } \\
\text { activities? }\end{array}$ & 82,6 \\
\hline 2 & Want to be an entrepreneur? & 86,5 \\
\hline 3 & $\begin{array}{l}\text { Agree if entrepreneurs can be } \\
\text { a solution for job seekers? }\end{array}$ & 96,1 \\
\hline 4 & $\begin{array}{l}\text { Want to develop renewable } \\
\text { energy can be developed into } \\
\text { entrepreneurship? }\end{array}$ & 76,9 \\
\hline 5 & $\begin{array}{l}\text { Want to develop food and } \\
\text { beverage fermentation can be } \\
\text { developed into } \\
\text { entrepreneurship? }\end{array}$ & 96,1 \\
\hline Average & 89,26 \\
\hline
\end{tabular}

\subsection{Discussion}

\subsubsection{Student Interest in Textbooks}

Textbooks are a learning resource developed to support the lecture process [3]. As a learning resource, textbooks should be required to be provided, facilitated, or owned by the university [4]. Textbooks are also a printed learning media. As a media, textbooks have an important role in delivering information from lecturers to students. Not just being a media, textbooks can also have several important roles in supporting lectures:

a) Provide knowledge to students [5].

b) Provide motivation for the formation of certain behaviors and can provide instructions for to do something [6].

c) as a source of reading and reduce student dependence on lecturers [7].

d) Helping lecturers prepare students as future generations [8].

Based on the role of this textbook, the use of textbooks should be applied to biotechnology lectures. This is also in accordance with the response of $96.7 \%$ of students who expressed interest in textbooks in lectures. 


\subsubsection{Student's Experience in Entrepreneurship Activities}

Entrepreneurship is the study of one's values, abilities and behavior in responding to life's challenges and ways to obtain opportunities with various risks that may be faced [9]. Entrepreneurship will also make someone able to think creatively and have a forward orientation in living his life [10].

Generally, entrepreneurship activities include planning, promotion and sales. Planning is needed as a guide in developing products to entrepreneurship [9]. But, promotion and sales are two activities that are mutually sustainable.

Based on the results of the questionnaire that $68.5 \%$ of students have experience in these 3 entrepreneurship activities. This is an important capital to develop entrepreneurial spirit in students and education is a factor that can influence it [11].

\subsubsection{Interest in Developing Biotechnology Knowledge in the Field of Entrepreneurship}

Universities have become an important forum for preparing generations, especially for taking demographic bonuses in

\section{CONCLUSION}

Based on the discussion, it can be concluded that entrepreneurship-based biotechnology textbooks are needed and must be developed. The purpose of developing this textbook is as a reference for biotechnology lectures, so that lectures not only provide biotechnology knowledge but also provide biotechnology applications to entrepreneurship. Then, it is a big hope that the Indonesian generation can optimize demographic bonuses in the future.

\section{REFERENCES}

1. Prasetyo, H., \& Sutopo, W. (2018). Industri 4.0: Telaah Klasifikasi aspek dan arah perkembangan riset. J@ ti Undip: Jurnal Teknik Industri, 13(1), 17-26.

2. Undang-Undang U Nomor 12 tahun 2012 tentang Pendidikan Tinggi

3. Pratama, A, M., Amin, M., dan Suarsini, E., (2016). Pengembangan Buku ajar Bioteknologi di Universitas Jember. Jurnal Pendidikan: Teori, Penelitian, dan Pengembangan, Nomor 10 Volume 1, EISSN: 2502-471X, 1987-1992

4. UU nomor 12 tahun 2012 Tentang Pendidikan Tinggi

5. Pambudiono, A., Suarsini, E., dan Amin, M., (2016). Pengembangan Buku ajar Bioteknologi Berbasis Penelitian Bioremediasi Logam Berat the era of the industrial revolution 4.0. So, student interest in entrepreneurial activities must also get attention. Textbooks can be a solution in accommodating this, through the integration of biotechnology and entrepreneurship.

Integrating biotechnology and entrepreneurship programs can be called an effort to implement entrepreneur education. The aim of the Education of entrepreneurship is to change the mind set of students from job seekers to job creators [12].

a) In addition, entrepreneurship education can also have a number of positive effects on students:

b) Provide entrepreneurial knowledge to students [13].

c) Influencing student interest in entrepreneurship [14].

d) Growing an entrepreneurial spirit [15].

So, the use of entrepreneurship-based textbooks in lectures is expected to provide biotechnology knowledge and also the application of that knowledge to the entrepreneur field. This effort is also expected to help prepare students to take industrial-era demographic bonus 4.0.

Kadium untuk Mahasiswa S1 Biologi Universitas Jember. Jurnal Pendidikan: Teori, Penelitian, dan Pengembangan, Nomor 6 Volume 1, EISSN: 2502-471X, 1077-1085

6. Pribadi, A, Benny,. (2017). Media dan Teknologi dalam Pembelajaran, Jakarta: Kencana

7. Susanto, H., (2013). Teknik Peyusunan Bahan ajar. Disampaikan pada workshop penyusunan bahan ajar di Universitas Muhammadiyah, Semarang

8. Baburkin, S. A., Talanov, S. L., dan Lymarev, A. V. (2016). Vision of the Future and Values of University students. European Journal of Natural History, (6), 125-127.

9. Suryana. (2014). Kewirausahaan; Kiat dan Proses Menuju Sukses, Jakarata: Salemba Empat

10. Winardi. ((2015). Entrepreneur dan Entrepreneurship. Jakarta: Kencana

11. Siswadi, Y. (2014). Analisis faktor internal, faktor eksternal dan pembelajaran kewirausahaan yang mempengaruhi minat mahasiswa dalam berwirausaha. Jurnal Ilmiah Manajemen dan Bisnis, 13(1).

12. Ranto, D. W. P. (2016). Membangun Perilaku Entrepreneur Pada Mahasiswa Melalui Entrepreneurship Education. Jurnal Bisnis, Manajemen, dan Akuntansi, 3(1). 
13. Ahsin, M. N., dan Arumsari, N. R. (2018).

Pengembangan Bahan Ajar Bahasa Indonesia SD

Berbasis Kewirausahaan Untuk Menumbuhkan

Jiwa Entrepreneurship pada Generasi Muda.

Jurnal Pendas, 4(2), 91-103.

14. Dewi, C. A., Anggriani, M., dan Pahriah, P.

(2018). Pengembangan Perangkat Pembelajaran

CTL Berbasis Entrepreneurship untuk

Meningkatkan Motivasi Belajar Siswa pada

Materi Minyak Bumi. In Prosiding Seminar

Nasional Lembaga Penelitian dan Pendidikan

(LPP) Mandala (pp. 129-141).

15. Utami, C. W. (2017). Attitude, Subjective Norm, Perceived Behaviour, Entrepreneurship Education and Self Efficacy Toward Entrepreneurial Intention University Student In Indonesia. 